\title{
CLCN7 wt Allele
}

National Cancer Institute

\section{Source}

National Cancer Institute. CLCN7 wt Allele. NCI Thesaurus. Code C105878.

Human CLCN7 wild-type allele is located in the vicinity of 16p13 and is approximately 31 $\mathrm{kb}$ in length. This allele, which encodes $\mathrm{H}(+) / \mathrm{Cl}(-)$ exchange transporter 7 protein, is involved in chloride ion transport. Mutation of the gene is associated with both osteopetrosis autosomal dominant type 2 and osteopetrosis autosomal recessive type 4. 